\title{
SUPERCRITICAL FLUID TECHNOLOGY AND SUPERCRITICAL FLUID CHROMATOGRAPHY FOR APPLICATION IN GINSENG EXTRACTS
}

\author{
MAYYA PETROVNA RAZGONOVA ${ }^{1}$, ALEXANDER MIKHAILOVICH ZAKHARENKO ${ }^{1}$, \\ TATIANA KUZMINICHNA KALENIK ${ }^{2}$, ALEXANDER EVGENYEVICH NOSYREV ${ }^{3}$, ANTONIS \\ K. STRATIDAKIS ${ }^{4}$, YAROSLAV OLEGOVYCH MEZHUEV ${ }^{5}$, TATYANA I. BURYKINA ${ }^{6}$, \\ ALINA CRENGUȚA NICOLAE ${ }^{7}$, ANDREEA LETIȚIA ARSENE ${ }^{7}$, ARISTIDIS MICHAEL \\ TSATSAKIS $^{3,4,5}$, KIRILL SERGEYEVICH GOLOKHVAST $^{1,8 *}$
}

\author{
${ }^{1}$ Scientific Education Center in Nanotechnology, Far-Eastern Federal University, Vladivostok, Far East, Russian Federation \\ ${ }^{2}$ School of Biomedicine, Far-Eastern Federal University, 690950, Vladivostok, Far East, Russian Federation \\ ${ }^{3}$ Central Chemical Laboratory of Toxicology, I.M. Sechenov First Moscow State Medical University, Moscow, Russian Federation \\ ${ }^{4}$ Laboratory of Toxicology, School of Medicine, University of Crete, Heraklion 71003, Greece \\ ${ }^{5}$ Dmitry Mendeleev University of Chemical Technology of Russia, Miusskaya Square, 9, Moscow 125047, Russian Federation \\ ${ }^{6}$ Department of Analytical and Forensic Medical Toxicology, Sechenov University, Moscow 119991, Russian Federation \\ ${ }^{7}$ Faculty of Pharmacy, "Carol Davila" University of Medicine and Pharmacy, Bucharest, Romania \\ ${ }^{8}$ Pacific Geographical Institute FEB RAS, 7 Radio street, Vladivostok, 690041, Russian Federation
}

*corresponding author: golokhvast.ks@dvfu.ru

Manuscript received: August 2018

\begin{abstract}
This research review deals with the study of the scientific articles, published during the last two decades that are devoted to the extraction of ginsenosides from different types of ginseng with the use of supercritical $\mathrm{CO}_{2}\left(\mathrm{SC}-\mathrm{CO}_{2}\right)$. Different types of ginseng are being the object of investigation including Panax ginseng C.A. Meyer, Brazilian ginseng (Pfaffia paniculata, Pfaffia glomerata, Hebanthe eriantha) and North American ginseng (Panax quinquefolius). It was shown that the extraction and fractionation of Panax ginseng C.A. Meyer using $\mathrm{SC}^{-\mathrm{CO}_{2}}$ technology is a very effective way for extracting biologically active plant components, such as ginsenosides, kudinosides, polysaccharides, polyphenolic compounds and stauntosides. In addition, it was exhibited that $\mathrm{SC}-\mathrm{CO}_{2}$ technology could increase considerably the yield in antioxidant fractions in which the concentration of bioactive components of a $P$. ginseng C.A. Meyer are high. At last, this review also considers the application of supercritical $\mathrm{CO}_{2}$ fluid chromatography for Panax ginseng. The review aspired to investigate the contents and to compare other ways of extraction with supercritical extraction and to show its efficiency and also use of new "green technologies".
\end{abstract}

\section{Rezumat}

Această lucrare reunește articolele ştiințifice publicate în ultimele două decade privind extracția ginsenozidelor din diferite varietăți de ginseng, utilizând dioxid de carbon supercritic. Printre varietățile de ginseng ce fac obiectul cercetării se află Panax ginseng C.A. Meyer, ginsengul brazilian (Pfaffia paniculata, Pfaffia glomerata, Hebanthe eriantha) și ginsengul american (Panax quinquefolius). S-a demonstrat că extracția și fracționarea Panax ginseng C.A. Meyer, utilizând dioxid de carbon supercritic, reprezintă metode eficiente pentru extracția principiilor biologic active ale plantelor, precum ginsenozide, kudinozide, polizaharide, compuși polifenolici și stauntozide. În plus, s-a arătat că tehnologia de extracție cu dioxid de carbon supercritic poate îmbunătăți considerabil randamentul obținerii fracțiilor antioxidante în care concentrația componentelor bioactive ale $P$. ginseng C.A. Meyer este ridicată. În final, acest review ia în considerare aplicabilitatea cromatografiei de lichide supercritice cu $\mathrm{CO}_{2}$ pentru extracția principiilor active din Panax ginseng. Lucrarea actuală încearcă să investigheze structura metodelor de extracție, să compare extracția de fluide supercritice cu alte tehnologii de extracție, și să demonstreze eficiența și necesitatea utilizării noilor tehnologii ecologice.

Keywords: supercritical fluid technology, ginseng extracts, Panax ginseng, ginsenosides

\section{Introduction}

Vast research and experience in traditional medicine in the Far Eastern countries, originated from the ancient times, opened new possibilities to meet the needs of modern medicine and pharmacology. A great part of this research studies the development of novel technologies for the extraction of Panax ginseng, a vegetal product/plant which belongs to the family of Araliaceae. Extended studies have demonstrated the therapeutic uses of plant extracts through the years [1-7]. More specifically previously conducted studies have exhibited the valuable medicinal use of Panax ginseng [8-10]. The first data for this herb refers to the remote past and is surrounded by an aura of legends. During many centuries ginseng was a subject of worship of the Far Eastern people and 
FARMACIA, 2019, Vol. 67, 2

played a great part in culture, trade and even in foreign policy of China and other East-Asian countries.

Ginseng is found in three types in East Asia and in two types in North America. P. ginseng C.A. Meyer can also be found in Japan under the name Panax japonica C.A. Meyer and in the Himalayas under the name Panax pseudoginseng Wall., Panax trifolius L. has been widespread in North America and mainly $P$. quinquefolius as well as 'American ginseng'. The place of its growth is a northern part of the USA and the southern regions of Canada.

\section{Structure of main ginsenosides and polyacetylenes}

Ginseng consists of many ingredients such as phenolic compounds, amino acids, proteins, polysaccharides, alkaloids, polypeptides, kudinosides, vitamin $\mathrm{B}_{1}$ and $\mathrm{B}_{2}$ [11]. The most important components in $P$. ginseng C.A. Meyer are ginsenosides, which belong to the family of the saponins having triterpenoid dammarane structure. More than 100 types of ginsenosides with differing structures have been already found [12]. As saponins have various structural characteristics, they exhibit various pharmaceutical properties. Many previously conducted studies have demonstrated applications of ginseng for the treatment of diseases like antioxidant capacity [13, 14], protective effects on cardiovascular system [15, 16], maintenance of the immune system [17,18], prevention of diabetes [19, 20], anti-obesity [21] and anti-cancer activity.

Saponins are high molecular weight glycosides called aglycone and belong to the triterpene group. This group of amphiphilic compounds affects the strength of superficial and interphase effects of these substances [22].

Although studies concerning the surface-active properties of a phytogenesis have been generally made with the use of Quillaja saponins [23, 24], the soya saponins [25], P. ginseng C.A. Meyer [26], and saponins from Ziziphus joazeiro and Agave sisalana [27].

The most known active components (ginsenosides) and polyacetylenes of $P$. ginseng C.A. Meyer are: 20S-protopanaxadiol, Panaxadiol, Ginsenoside $a_{1}$, Ginsenoside $a_{2}$, Ginsenoside $R b_{1}$, Ginsenoside $R b_{2}$, Ginsenoside $\mathrm{Rb}_{3}$, Ginsenoside $\mathrm{Rg}_{3}$, Ginsenoside $\mathrm{Rh}_{2}$, Ginsenoside $\mathrm{Rh}_{3}$, 20S-protopanaxatriol, Panaxatriol, Ginsenoside $\mathrm{Rg}_{1}$, Ginsenoside $\mathrm{Rg}_{2}$, Ginsenoside $\mathrm{Rg}_{4}$, Notoginsenoside $\mathrm{R}_{1}$, Ginsenoside $\mathrm{Re}$, Ginsenoside $\mathrm{Rh}_{1}$, Notoginsenoside ST4, GinsenosideR $\mathrm{R}_{10}$, Ginsenoside $\mathrm{R}_{0}$, Falcarinol, Falcarintriol.

Traditional extraction methods for ginsenoside isolation from ginseng include ultrasound assisted extraction, Soxhlet-extraction, and microwaveassisted extraction [28-30]. Some of the standard extraction methods have long-term extraction times and larger quantities of solvent, which may result in the thermal instability of the objective components. Moreover, a succeeding filtration and/or sequential concentration is often demanded to remove the solid residue [28]. Supercritical fluid $\mathrm{CO}_{2}$ extraction \pm polar modifier has shown considerable profit in the extraction of medicinal plants [31-34]. It is so-called new "green technology". It has no need to use such solvents as ethanol, propanol, methanol and other alcohols. Due to this fact, the need for solvent consumption is minimized as in the final stage there is no need for purification of the extract from these solvents.

\section{Progress of supercritical technology}

The use of supercritical fluids (SCF) as applied to the treatment of food materials has begun since the late 1960s and introduces the most prosperous application of SCFs.

In King's review [34] on the progress of SCF technology, the use of subcritical fluids, and mixed fluids under varying degrees of compression has been registered in many subsidiary of biotechnological, pharmaceutical, food, biochemical industry during the past 43 years. First successful experience in the food industry for decaffeinating coffee [36] and the use of $\mathrm{SC}-\mathrm{CO}_{2}$ in release extracts of hop for aromatization of beer [37] were the first interesting applications of this technology. Supercritical fluid extraction (SFE) and supercritical fluid chromatography (SFC) have been widely used since the late 1970 s for the analysis of food quality and for the specification of fat levels in food [38] and trace levels of toxic components [39].

Enzyme-catalyzed reactions have made the greatest contribution to food technologies [40], hydrogenations to control particular trans isomers existing in lipid mixtures [41] and hydrolysis accompanied in the presence of enzymes or the subcritical water [42]. A significant increase in the production of fine particles for use in the pharmaceutical industry began in the 1990s. The last 20 years; the focus was shifted to a combination of SCF technologies in the food industry and the production of biologically active substances from plant matrices [43].

The active development of SFE and SFC methods for the production of nutraceuticals, functional food compositions and herb extracts for medical purposes and bioactive food additives began [44, 45]. The use of green processing technology made it possible to obtain products that do not contain solvents, which also positively affects the care for the ecology in order to preserve the environment in the $21^{\text {st }}$ century [46]. Recently, the same problems began to be solved in the production of renewable bioenergy (bioethanol and biodiesel) and the extraction of food products $[47,48]$. The concept of 
FARMACIA, 2019, Vol. 67, 2

bio-resources [49], most likely offers a solution to the issue of choice between food and fuel, which is often mentioned in modern scientific publications [50].

Supercritical extraction is used in multiple processes: processing sequences for extracting, fractionating, and reacting naturally derived materials to desired end products.

Solute solubility and diffusion are equally important in SCF to achieve the maximum flow of solute in SFE. When using SFE, for example removing pesticides from ginseng, the process of mass transfer of the dissolved substance from the food matrix becomes very important.

In 1980s, a method for fractionating extracted solutes was developed using SFE, supercritical fluid fractionation (SFF). The extract obtained by supercritical extraction was fractionated to obtain the desired composition or to increase the concentration of certain solutes compared to their concentration in the initial extraction. The process of SFF can be kept under strict control, if it is possible to change extraction conditions: pressure, extraction temperature and extraction time. There are two main ways to perform SFF: fractionation using columns and supercritical chromatography (SFC/SFF, made using ready-made columns, is partially similar to distillation, except that SCF compresses through the column during compression and usually contacts the liquid support in countercurrent mode [32].

To improve the separation of components in the initial mixture, a temperature gradient is also used; so the separation on the column is based on a temporary change in the density of the liquid by pressure and a temperature gradient, respectively creates a fluid density gradient in the longitudinal direction along the column of the chromatograph.

Therefore, the extract (the top of the column) and the raffinate (the bottom of the column) are separated based on their solubility in the dense liquid and their volatility, which depends on temperature. A large number of natural plant compounds were fractionated using a column approach, for example: marine oils [49], glycerides [50], tocopherols [53], free fatty acids [54], phytosterols [55], extract components of essential oil [56].

SFC on a preparative or production scale has not seen much commercial use despite several studies on tocopherol-, phytosterol-, and phospholipidladen substrates. Isolation of function ingredients from rosemary has been accomplished by preparative SFC [57]. SFC with simulated moving bed (SMB) was used to isolate ethyl oleate [58]. Also, SFC was applied to the study of omega fatty acids contained in fish and algae, further stimulating additional interest in this complex SFF method [59].

\section{Classical description extraction process of ginsenosides}

Previously Wang et al. [60] reported about the isolation of ginsenosides and essential oils from $P$. ginseng C.A. Meyer using SFE.

This research examined in detail the process of supercritical extraction of ginseng oil from $P$. ginseng C.A. Meyer root hairs. The extraction efficiency of $\mathrm{SC}^{-\mathrm{CO}_{2}}$ at $31.2 \mathrm{MPa}, 333 \mathrm{~K}, 660$ liters of $\mathrm{CO}_{2}$ with the addition of ethanol $6 \mathrm{~mol} \%$ was comparable to the extracted result with ethanol extraction. It should also be noted that the amount of oil extracted at a constant temperature increases with an increase in pressure exceeding 24.2 MPa. The largest quantities of oil and ginsenoside were $0.1 \mathrm{~g} / \mathrm{g} P$. ginseng C.A. Meyer and $1141 \mathrm{mg}$ per $\mathrm{kg}$ of absorbent.

The result of the extraction of ginseng was presented as a ratio of the weight of the extracted oil to the weight of the ginseng in the extractor. In a study, McHugh and Krukonis [61] showed that the solubility of a substance in a supercritical fluid depends on the density of the solvent and the level of volatility of the solute. The main factors influencing the extraction efficiency of ginseng are the density of $\mathrm{CO}_{2}$, the diffusion of $\mathrm{CO}_{2}$ into the ginseng and the volatility of ginseng oil.

The experiments carried out by Wang et al., [60] showed that the density of the $\mathrm{CO}_{2}$ solvent is proportional to the yield of ginseng oil. At a pressure in the range of 24.2 to $31.2 \mathrm{MPa}$, the temperature increase improved the extraction result. At a lower pressure of $10.4 \mathrm{MPa}$, the extraction result was not as effective. Thus, the optimum extraction conditions were found at a temperature of $333 \mathrm{~K}$ and a pressure of $31.2 \mathrm{MPa}$. Similar results were obtained using supercritical extraction for the extraction of biologically active plant substances such as soybean oil and oil and waxes from rice bran $[62,63]$.

The addition of a polar modifier affects the increase in extraction of ginseng oil and the extraction of six basic ginsenosides. The increase in solubility due to the effect of the modifier is possible due to an increase in the density of the solvent, and also due to a specific chemical interaction, for example hydrogen bonding. Under extraction conditions, temperature $333 \mathrm{~K}$ and pressure $31.2 \mathrm{MPa}$, the addition of EtOH modifier from 0 to $6 \mathrm{Mol} \%$ increased three times the extraction yield of ginsenosides. As a result of the experiments it was also proved that the temperature of the process directly affects the yield of the extracted oil and the content of ginsenosides. 


\section{Supercritical extraction of other types of Ginseng}

Wood et al. [64] investigated the root of North American ginseng ( $P$. quinquefolius). The ginseng root was extracted by two methods: Soxhlet extraction and SFE. Supercritical extraction was enhanced with $\mathrm{MeOH}$ and DMSO modifiers. In the experiments, it was shown that the increase in pressure did not significantly affect the amount of extracted ginsenosides extracted (pressure range 20.7-48.3 $\mathrm{MPa}$ using the $\mathrm{MeOH}$ modifier, and it was separately shown that this process is limited by mass transfer / desorption.) In these conditions, SFE was extracted to $90 \%$ of the total amount of ginsenosides compared to Soxhlet extraction, which was additionally proved by the HPLC method.

HPLC analysis of the extract revealed the presence of six basic ginsenosides $\mathrm{Rb}_{1}, \mathrm{Rb}_{2}, \mathrm{Rc}, \mathrm{Rd}, \mathrm{Re}, \mathrm{Rg}_{1}$.
Court et al. [65] pointed out that 4 malonyl ginsenoside are present in significant amounts in ginseng, but malonyl ginsenosides are thermally unstable. The peaks of $\mathrm{Re}$ and $\mathrm{Rg}_{1}$ were not completely resolved by HPLC analysis, but Assinewe et al. [66] noted that ginsenoside $\mathrm{Rg}_{1}$ is a small component relative to $\mathrm{Re}$ in the $P$. quinquefolius root, so the $\mathrm{Re} / \mathrm{Rg}_{1}$ peak consists mainly of ginsenoside Re.

Wood et al. [64] discovered a significant unknown peak in the ginsenoside region when analyzing SFE extracts. This peak appeared during the extraction of $\mathrm{CO}_{2}+$ modifier (DMSO). LC / MS was used to determine this peak. Based on the analysis of mass spectra, the unknown peak HPLC corresponded to $\mathrm{m} / \mathrm{z}$ for $[\mathrm{M}-\mathrm{H}]-1149.7$.

Kite et al. [67] asserted that the peak at this $\mathrm{m} / \mathrm{z}$ ratio corresponds to the quinquenoside $\mathrm{R}_{1}$ (Figure 1), mono- $O$-acetyl ginsenoside $\mathrm{Rb}_{1}$.

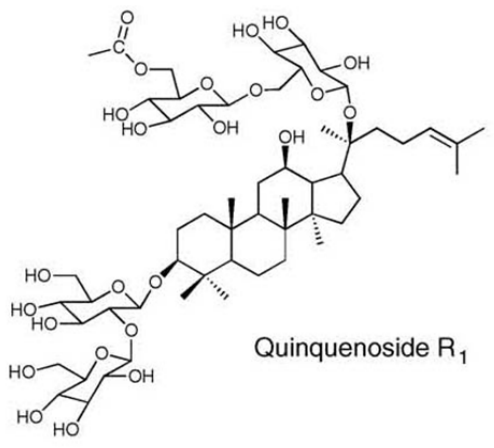

Figure 1.

Structure of quinquenoside $\mathrm{R}_{1}$ (mono-acetylated $\mathrm{Rb}_{1}$ )

In the total content of ginsenosides mono-acetate do not play a significant role [65]. Lipase $B$ of Candida antarctica was used for regioselectively acetylation of ginsenoside $\mathrm{Rb}_{1}$ [68]. Wood et al. [64] showed that two mono-acetate compounds, 6"$\mathrm{O}$-acetylginsenoside $\mathrm{Rb}_{1}$ and 6" "-O-acetylginsenoside $\mathrm{Rb}_{1}$ were formed. These compounds did not differ in the MS analysis, and it was necessary to use NMR to determine that one MS peak corresponds to two compounds of mono-acetate ginsenoside $\mathrm{Rb}_{1}$ [68].

It has also been found that supercritical extraction with both the methanol modifier and the DMSO modifier gives relatively large amounts of monoacetylated ginsenosides (6"/6"'- O-acetyl ginsenoside $\mathrm{Rb}_{1}$.) Therefore, it is possible to draw a general conclusion that SFE can produce extracts of ginsenoside with high biological activity due to the increase in the variety and the amount of extractable compounds.

Denglin Luo et al. [69] studied the SFE of ginsenosides from Ginseng, amplified by ultrasound and reverse microemulsions formed by
Bis (2-ethylhexyl) sulfosuccinate sodium salt) (AOT). The intensity and frequency of the ultrasound used for the SFE extraction, amplified by reverse microemulsions, were $7.6 \mathrm{~W} / \mathrm{cm}^{2}$ and 20 $\mathrm{kHz}$, respectively. The duration of continuous ultrasonic irradiation was 3 seconds with an interval of 6 seconds. The kinetics of extraction of ginsenosides has been studied: SFE; Extraction enhanced by reverse microemulsions of $\mathrm{SC}-\mathrm{CO}_{2}$ (SCRME); Extraction of $\mathrm{SC}-\mathrm{CO}_{2}$ by reverse microemulsions amplified by ultrasound (USCRME). The extraction mechanisms were different for SFE and SCRME.

Ginsenosides did not dissolve in SFE below 40 $\mathrm{MPa}$, because $\mathrm{CO}_{2}$ is a non-polar solvent. In SCRME, ginsenosides dissolve in aqueous pools of reverse microemulsions. The solubility of ginsenosides depends on the polarity, size and amount of water basins. The result of 4 hours of SCRME extraction was 3.23 times higher than SFE. The extraction yield of USCRME ginsenosides after 4 hours was 1.82 times higher than when extraction of SCRME. This experiment confirms that ultrasound significantly 
FARMACIA, 2019, Vol. 67, 2

improves the supercritical extraction of ginsenosides, enhanced by reverse microemulsions. The amplification of ultrasound SCRME is associated with mechanical vibrations and the positive effect of ultrasound on temperature. Ultrasound can create pulsations in a supercritical environment; micelles, respectively, increase in size to dissolve more ginsenosides. Also polar molecules can easily penetrate into micelles as a result of mechanical vibrations, respectively increase mass transfer.

The different intensity of ultrasound had a different effect, depending on the concentration of the reverse microemulsions. The effect of sufficiently low ultrasound intensity at a low AOT concentration on the extraction result was more effective than high ultrasound intensity. A high concentration of AOT, coupled with a high intensity of ultrasound gave the best result of extraction of ginsenosides, than a low intensity of ultrasound.

The general conclusion is the following: at a low concentration of the surfactant, the micellar structures of the reverse microemulsions are destroyed by high-intensity ultrasound, and ultrasound with low intensity stimulates an increase in the extraction of ginsenosides dissolving in the micellar polar nuclei. This effect is the main reason for the formation of various dependencies on small concentrations $(0.03$ and $0.05 \mathrm{~mol} / \mathrm{L})$ and large concentrations $(0.07$ and $0.09 \mathrm{~mol} / \mathrm{L})$.

$\mathrm{Yu}$ et al. [70] observed a continuous fractionation of ginsenosides and polysaccharides from $P$. ginseng using $\mathrm{SC}-\mathrm{CO}_{2}$. These researchers used the continuous fractionation of supercritical $P$. ginseng to produce ginsenosides and polysaccharides. The following fractionation conditions were used: three temperatures $(40,50$ and 60$)$, three pressure levels $(10,20$ and $30 \mathrm{MPa})$, three $\mathrm{SC}-\mathrm{CO}_{2}$ flow rates $(2,4$ and $6 \mathrm{~mL} / \mathrm{min})$ and three ginseng extract flow rates $(1,2$ and $3 \mathrm{~mL} / \mathrm{min})$. Fraction $\mathrm{F}$ showed the highest concentration of ginsenosides, and the maximum concentration of polysaccharides was obtained in the residue. The best fractionation of ginsenosides and polysaccharides was achieved at 60 and $30 \mathrm{MPa}$.

According to Reverchon et al. [32], the vapor pressure and the density of the solvent affect the solubility of $\mathrm{SC}-\mathrm{CO}_{2}$. Improvement of extractability with increasing pressure is associated with an increase in the density of $\mathrm{CO}_{2}$ [71]. A high concentration of vitamin E in Spirulina extracts [72] is associated with an increase in supercritical extraction pressure and temperature. It was found that the best conditions for extraction of ginsenosides and polysaccharides are $30 \mathrm{MPa}$ and 40 in the study by $\mathrm{Yu}$ et al. [70]. The experimental results showed that the total amount of polysaccharides in the $\mathrm{R}$ fraction glucose equivalent is $0.149 \mathrm{~g} / 100 \mathrm{~g}$ dry weight, and the total concentration of ginsenosides in $\mathrm{F}$ fraction is 1.958 $\mathrm{g} / 100 \mathrm{~g}$ dry weight, respectively.

As indicated above, the increased $\mathrm{SC}-\mathrm{CO}_{2}$ rate and the flow rate of the extraction liquid improve the solubility of the ginsenosides in the $\mathrm{F}$ fraction and insoluble polysaccharides in the $\mathrm{R}$ fraction $[32,71]$. The ability to remove 2,2-Diphenyl-1picrylhydrazyl (DPPH) radicals increased with increasing concentration of ginseng fractions.

DPPH is a stable free radical that is widely used to evaluate plant extracts as free radical scavengers [73]. Ginseng extracts, according to $\mathrm{Hu}$ and Keats [74], exhibit good results in the binding of free radicals, and it is suggested that this effect is associated with a high content of ginsenosides in the extract. Since fractionation can increase the concentration of ginsenosides in fraction $\mathrm{F}$, the greatest effect on the derivation of free radicals was observed in fraction $\mathrm{F}$.

The best inhibition effect was shown by fraction $\mathrm{F}$ $(63 \%)$ at $5.0 \mathrm{~g} / \mathrm{L}$, followed by $\mathrm{R}(40 \%)$ and $\mathrm{E}$ (38\%). Concentrations of 3.2, 8.7 and $9.0 \mathrm{~g} / \mathrm{L}$ are necessary to inhibit the formation of $50 \%$ of 2,2'azinobis- (3-ethylbenzothiazolin-6-sulfonic acid) diammonium salt $\left(\mathrm{ABTS}^{+}\right)$for $\mathrm{F}, \mathrm{R}$ and $\mathrm{E}$, respectively, since reactive oxygen species are produced that can interact with biological molecules, ultimately damaging membranes and other plant tissues [75]. With the help of this study, it is possible to develop effective methods for obtaining ginsenosides and polysaccharides from ginseng without the presence of toxic solvent residues in the final product, which is very important for the environmental expectations of consumers.

Chien et al. [76] investigated the content and antioxidant activity of various fractions of powder extract from $P$. ginseng C.A. Meyer root using SC$\mathrm{CO}_{2}$ for fractionation. The results showed that the activity of the DPPH radicals was higher in the residue and fraction 1 compared to the activity in the extract. The increase in the number of phenolic compounds, polysaccharides and saponins is also directly dependent on higher antioxidant activity. The general conclusion of the study is that: the technology of fractionation with $\mathrm{SC}-\mathrm{CO}_{2}$ can efficiently isolate biologically active substances from $P$. ginseng C.A. Meyer and increase the antioxidant activity of its fractions.

Bitencourt et al. [77] studied the extraction of saponins from Brazilian ginseng using $\mathrm{SC}-\mathrm{CO}_{2}$, ethanol and water. Saponins, in addition to the pronounced pharmacological effect, are also surface-active substances that reduce the surface tension of aqueous solutions. Extracts of the roots of Brazilian ginseng P. glomerata and H. eriantha 
FARMACIA, 2019, Vol. 67, 2

roots using supercritical technology were obtained using $\mathrm{SC}-\mathrm{CO}_{2}$, ethanol and water as modifiers. All extractions were carried out in four stages at a temperature of 50 and 300 Bar. In the first stage, pure $\mathrm{SC}-\mathrm{CO}_{2}$ served as the solvent. Subsequent steps (a) $\mathrm{SC}-\mathrm{CO}_{2} /$ ethanol mixers $(70: 30, \mathrm{v} / \mathrm{v})$; (b) ethanol and (c) ethanol/water $(70: 30, \mathrm{v} / \mathrm{v})$. Thin layer chromatography (TLC) and surface tension were used to analyze the extracts. The results of extraction of four stages for the roots of $P$. glomerata and for the roots of $H$. eriantha showed the predominance of compounds of high polarity. TLC analysis showed that the extraction process is selective in accordance with the polarity of the solvent, and the extracts contain various saponins. Extraction using $\mathrm{SC}-\mathrm{CO}_{2}$ and ethanol as a modifier showed the greatest ability to reduce the surface tension of water from $72 \mathrm{mN} / \mathrm{m}$ (pure water) to 25 $\mathrm{mN} / \mathrm{m}$, indicating that this kind of solvent is best suited for extracting saponins with lower polarity.

In both types of Brazilian ginseng samples were taken at short intervals for generation of curves extraction. The third extraction was carried out in such a way that only the sample of each stage was removed for evaluation by TLC and surface tension.

The extract mass curve, depending on the extraction time, clearly showed that the extraction rate decreased in the last hours of the process, since approximately $75 \%$ of the extract in this step was recovered within the first 3 hours. The last two steps using ethanol (polarity: 5.2) as solvents and one mixture of ethanol and water (polarity 9.0) were used as solvents for 6 hours each extraction, and 68 and $72 \%$ extract, respectively, were obtained in the first 3 hours.

The extraction process is highly dependent on the polarity of the solvent and various saponins are present in the extracts (as indicated by TLC analysis). The extracts obtained with $\mathrm{SC}-\mathrm{CO}_{2}+$ ethanol (stage 2) showed the greatest ability to reduce the surface tension of water from $72 \mathrm{mN} / \mathrm{m}$ (pure water) to $25 \mathrm{mN} / \mathrm{m}$. This point shows that this extraction option was the best for extracting the least polar saponins. The critical values of the micellar concentration (CMC) were approximately 2 and $8 \mathrm{~g} / \mathrm{L}$ for $P$. glomerata and $H$. eriantha, respectively. All the above experiments proved the efficiency of the extraction process under study.

Leal et al. [78] received and studied extracts of Brazilian ginseng from two species of $P$. paniculata and $P$. glomerata, which were obtained by SFE with $\mathrm{CO}_{2}$ and by low pressure solvent extraction (LPSE) with methanol, hexane and ethanol. SFE was carried out at pressures of 100, 200 and 300 bar and a temperature of 30 and 50 . The chemical composition of the extracts was determined by
TLC. The active natural compound from the extract of $P$. glomerata $\beta$-ecdysone (by HPLC) was isolated and identified. The antioxidant activity of the extracts was determined by the coupled reaction of linolenic acid and $\beta$-carotene. The best result of supercritical extraction for $P$. paniculata was obtained at $200 \mathrm{bar} / 50$. The best result of supercritical extraction for $P$. glomerata was obtained at $200 \mathrm{bar} / 30$. The effect of the density of $\mathrm{CO}_{2}$ on the quantitative extraction result was revealed.

The total yield of $P$. glomerata extraction using SC$\mathrm{CO}_{2}+$ ethanol was $0.56 \%$ (dry basis). This result is much better than the result obtained using only supercritical CO2 (0.18\%, at $200 \mathrm{bar} / 30$ ), as well as using ethanol only when extraction of LPSE $(0.4 \%)$ as a solvent. Leal et al. [78] concluded, that the solvent from $\mathrm{SC}-\mathrm{CO}_{2}$ and ethanol, as a modifier, has the highest solubility of natural plant matrices than pure solvents. The period of the constant extraction rate (tCER) is 134minutes. During this period, about $70 \%$ of the extract was obtained. tCER is the main indicator of how long industrial extraction will be performed [79]. TLC detected the presence of flavonoids in the extract for both Pfaffia species.

Quan et al. [80] developed a method for simultaneous SFE and purification of ginseng from nine organochlorine pesticides (OCP). Pesticides were represented by hexachloride $\alpha-, \beta-, \gamma$ - and $\delta$ benzene (BHC), pentchloronitrobenzene, as well as DDT and its metabolites. The isolated target compounds were collected by an autonomous commercial solid-phase extraction cartridge, then extracted with SFE and quantitated by gas chromatography with mass spectrometric confirmation. The best extraction conditions were obtained in experiments where the samples were pre-loaded by 10 wt. $\%$ ethanol in $\mathrm{H}_{2} \mathrm{O}$, an extraction pressure of 300 bar, an extraction temperature of 60 , and an adsorbent of the C18 trap and n-hexane as the eluting solvent were used. As the results of the experiment showed, SFE was a faster and more efficient method than Soxhlet extraction. Pressure is one of the most important physical parameters in SFE. The effect of pressure on the extraction of OCP from a ginseng sample was studied in five variation conditions. Extraction of most analytes increased with an increase in pressure from 150 bar to 300 bar.

Above the pressure limit of 300 bar, an unexpected reduction in recovery at 350 bar occurred, and a matrix distortion problem was revealed. Langenfeld et al. [81] found that the solubility of a substance in a SCF depends on two factors: the volatility of the substance and the dissolving power, which is directly related to the density of the SCF. There are probably two different effects of temperature 
influence during SFE: an increase in temperature can significantly increase the solubility of natural matrices, despite the decrease in density arising when the temperature is raised at constant pressure [74]; Many researchers [81-83] also suggests that an increase in temperature will lead to an increase in the extraction rate of the desorption process.

Three different temperature values $(40,50$ and 60 ) were used in the studies to assess the effect on the recovery of OCP. Extraction increased from 40 to 60 for most analytes, because the maximum solubility was reached at 60 .

Owen et al. [84] consider SFE with solid-phase capture as two separate extraction processes: SFE and solid-phase extraction. To obtain quantitative indices, the assays should effectively elute from the trap. The study of the applicability of various types of traps and eluents optimized the method. For possible adsorbents of the trap, silica gel, neutral aluminum and $\mathrm{C} 18$ were used; the eluents used are acetone, dichloromethane, n-hexane, and a $10 \mathrm{wt}$. $\% \mathrm{CH}_{2} \mathrm{Cl}_{2}$ in $\mathrm{n}$-hexane solution. DDT, DDD and DDE were not detected for Soxhlet extraction; the presence of BHC isomers and PCNB (pentchloronitrobenzene) was significant.

The best results were obtained using the $\mathrm{C} 18$ trap for all target analytes. It has been experimentally proved that SFE is more effective than Soxhlet extraction, and a trap with solid adsorption is a more effective method of collection.

\section{Supercritical fluid chromatography $P$. Ginseng}

Fractionation of triterpenoid saponins using SFC in combination with single quadrupole mass spectrometry was studied by Huang et al. [85]. An effective method was developed for the separation of saponins: kudinosides, stauntosides and ginsenosides contained in the root of $P$. ginseng C.A. Meyer, using SFC in combination with a single quadrupole mass spectrometry (SFC-MS). Separation conditions for selected biologically active substances have been carefully optimized after the initial selection of eight stationary phases.

Eight possible columns were used to select the most suitable columns for selecting the most suitable SFC (ZORBAX SB-C18, ZORBAX RX-SIL, X Amide, Venusil NP, Venusil PFP, Venusil ASB Phenyl, Venusil Imidazolyl, Venusil HILIC). All eight columns were of different polarity and with various chemical properties of the surface. As test analytes, nine kudinoside standards were selected, and the same gradient elution program was used for all eight columns.

Columns C18 with a reverse phase were usually used to fractionate triterpenoid saponins with liquid chromatography, while all nine of the kudinosides did not retain fixation at all on the ZORBAX SB-
C18 in SFC mode. Agrawal et al. [92] fractionated bacoside A3 and bacopaside II on this column, which is explained by the polar characteristics of ginseng saponins. A slightly increased retention for several kudinosides was observed on Venusil PFP, as well as on the columns of Venusil NP, but elution remained the main problem. ZORBAXRXSIL showed the best separation performance for all nine kudinoside standards from all eight tested columns. Therefore, the ZORBAX RX-SIL column was selected for further supercritical fractionation. Elution with ACN, EtOH, or IPA modifiers was not very successful, as there was too much retention of the kudinosides. Compared to these solvents, the use of $\mathrm{MeOH}$ as a mobile phase $\mathrm{B}$ component allows maximizing the resolution and reducing the erosion of the peak boundaries. As a result, $\mathrm{MeOH}$ was chosen as a modifier for all further experiments. Ashraf-Khorassani and Taylor L.T. [87] noted that water is also an interesting additive in SFC because of its good influence on the shape of the peak, as well as the reproducibility of the retention time. The maximum sensitivity of the column was obtained with water content of $8 \%$.

The water that interacts with $\mathrm{SC}-\mathrm{CO}_{2}$ becomes carbonic acid [88]. The role of water when added to SFC is significantly increased due to the simultaneous ability to be both a hydrogen bond acceptor and a hydrogen bond donor [89]. But with the increase in the water concentration to $12 \%$, the resolution and shape of the peaks worsened, because the $\mathrm{pH}$ of the solution varied [89].

The MS reactions of the kudinoside compounds were improved when a makeup solution containing 5 or 10 mM AA (ammonium acetate) was used, but a significant loss of signal strength was observed when the AA concentration reached $20 \mathrm{mM}$. To find the best separation characteristics, the effect of back pressure (from 140 to 200 bar) and temperature (from 20 to 35 ) was also investigated. The retention in this range depends in a lower limit on the changes in the back pressure.

Optimal conditions for the separation of SFC for kudinosides were obtained on an RX-SIL column at 160 bar and 20 . Water was used as a component of mobile phase B (30-50\%) in gradient elution. The best SFC result was obtained by adding water $(5-10 \%)$ and formic acid $(0.05 \%)$ to the SC$\mathrm{CO}_{2} / \mathrm{MeOH}$ mobile phase. Supercritical liquid chromatography showed a higher resolution and shorter operating time than reverse phase liquid chromatography. The SFC-MS methods have been successfully used to separate and identify triterpenoid saponins present in Ilex latifolia Thunb., P. quinquefolius L. and P. ginseng C.A. Meyer. SFC-MS is currently the most advanced tool for assessing the quality of products containing 
FARMACIA, 2019, Vol. 67, 2

triterpenoid saponins as biologically active substances [85].

Huang et al. [90], developed an effective analytical method was successfully developed for the simultaneous separation of 17 nucleotides, nucleosides and ginsenosides in ginseng extracts using supercritical liquid chromatography with SFC-MS. The influence of various experimental factors has also been studied: the type of column, temperature and back pressure, the type of modifier and additives, and the concentration of the solvent for make-up. This method has been successfully applied to assess the quality of 14 batches of ginseng extracts of various origins. The results show that this method can be used to assess the quality of ginseng extracts.

SFC of North American ginseng extract was studied by Samimi et al. [91]. SFC using $\mathrm{SC}-\mathrm{CO}_{2}$ is considered as a "green" separation method, particularly suitable for the isolation of thermally unstable bioactive components. However, a cosolvent and additives are often required in the mobile phase due to the poor solubility of the polar components in $\mathrm{SC}-\mathrm{CO}_{2}$. Acidic, basic and ionic additives were introduced into the mobile phase, respectively, to study their effect on the separation of ginsenosides. The best separation conditions were obtained by adding trifluoroacetic acid in methanol $(0.05 \% \mathrm{v} / \mathrm{v})$ at 50 and 150 bar. The concentrated component in SFE extracts of $P$. quinquefolius L. was isolated with SFC and determined as sucrose using NMR, HPLC and ESIMS. One can draw a general conclusion that SFC is a promising method for the separation, isolation and identification of ginseng extracts.

\section{Conclusions}

Pressure is the most important physical parameter in supercritical extraction. Along with temperature, pressure determines the density of the supercritical fluid, which directly correlates with solubility. The recovery of most analytes increased with an increase in pressure from 150 to 300 bar. The sharp decrease in extraction at 350 bar was surprising and requires additional studies, since the problem of interference in the plant matrix is very interesting. The increase in temperature can significantly increase the solubility of the analytes due to the significant saturated vapor pressure despite the decrease in density that occurs with increasing temperature at constant pressure. In addition, along with the increase of temperature, the kinetics of desorption process is expected to increase.

$\mathrm{SC}-\mathrm{CO}_{2}$ is an ideal liquid for supercritical extraction based on its chemical properties. On the contrary it exhibits limited possibilities in the decomposition of polar or high molecular weight particles, even under very high pressure. Carbon dioxide, even at high temperatures, has limited possibilities for the dissolution of polar molecules; however, the characteristics of SCF can be improved by adding modifiers or co-solvents.

The use of SCF as solvents is an interesting alternative for obtaining natural products of high quality without the obtaining of toxic residues. Extraction with supercritical carbon dioxide at high pressure is a great technique for obtaining natural thermolabile substances. In addition, the products do not contain residues of organic solvents, which occur with conventional extraction methods. The easy removal of the solvent from the final product, high selectivity and the use of moderate temperatures in the process represent the main advantage of supercritical technology, leading to a multiple increase in research for use in the food, pharmacological and cosmetology industries

\section{References}

1. Veskoukis AS, Tsatsakis AM, Kouretas D, Dietary oxidative stress and antioxidant defense with an emphasis on plant extract administration. Cell stress Chaperone, 2012; 17(1): 11-21.

2. Stagos D, Amoutzias GD, Matakos A, Spyrou A, Tsatsakis AM, Kouretas D, Chemoprevention of liver cancer by plant polyphenols. Food Chem Toxicol., 2012; 50(6): 2155-2170.

3. Tsiaoussis J, Vassilopoulou L, Nikolouzakis T, Rakitskii VN, Vakonaki E, Fragkiadaki P, Stivaktakis P, Tsatsakis AM, Biomolecular profile of colorectal cancer - the role of telomerase as a potent biomarker. Farmacia, 2017; 65(5): 643-659.

4. Skenderidis P, Kerasioti E, Karkanta E, Stagos D, Kouretas D, Petrotos K, Hadjichristodoulou C, Tsakalof A, Assessment of the antioxidant and antimutagenic activity of extracts from goji berry of Greek cultivation. Toxicol Rep., 2018; 5: 251-257.

5. Alkan EE., Celik I., The therapeutics effects and toxic risk of Heracleum persicum Desf. extract on streptozotocin-induced diabetic rats. Toxicol Rep., 2018; 5: 919-926.

6. Sani TA, Mohammadpour E, Mohammadi A, Memariani T, Yazdi MV, Rezaee R, Calina D, Docea AO, Goumenou M, Etemad L, Shahsavand $\mathrm{S}$, Cytotoxic and apoptogenic properties of dracocephalumkotschyi aerial part different fractions on calu- 6 and mehr-80 lung cancer cell lines. Farmacia, 2017; 65(2): 189-199.

7. Fenga C, Costa C, Caruso E, Raffa L, Alibrando C, Gangemi S, Docea AO, Tsatsakis AM, Current evidence on the protective effect of dietary polyphenols on breast cancer. Farmacia, 2016; 64(1): 1-12.

8. Wang W, Zhao Y, Rayburn ER, Hill DL, Wang H, Zhang E, In vitro anti-cancer and structure-activity relationships of natural products isolated from fruits of Panax ginseng. Cancer Chemotherapy \& Pharmacol., 2007; 59(5): 589-601. 
9. Reay JL, Kennedy DO, Scholey AB, Single doses of Panax ginseng (G115) reduce blood glucose levels and improve cognitive performance during sustained mental activity. $J$ Psychopharmacol., 2005; 19(4): 357-365.

10. Xie JT, Wang CZ, Wang AB, Wu J, Basila D, Yuan CS, Antihyperglycemic effects of total ginsenosides from leaves and stem of Panax ginseng. A Pharmacologica Sinica, 2005; 26: 11041110 .

11. Blumenthal M, The ABC Clinical Guide to Herbs. Thieme: New York, New York, 2003; 211-225.

12. Karmazyn M, Moey M, Gan XT, Therapeutic potential of ginseng in the management of cardiovascular disorders. Drugs, 2011; 71(15): 1989-2008.

13. Kim HG, Yoo SR, Park HJ, Lee NH, Shin JW, Sathyanath R, Cho JH, Son CG, Antioxidant effects of Panax ginseng C.A. Meyer in healthy subjects: a randomized, placebo-controlled clinical trial. Food Chem Toxicol., 2011; 49 (9): 2229-2235.

14. Kim KT, Yoo KM, Lee JW, Eom SH, Hwang IK, Lee CY, Protective effect of steamed American ginseng (Panax quinquefolius L.) on V79-4 cells induced by oxidative stress. $J$ Ethnopharmacol., 2007; 111 (3): 443-450.

15. Li J, Ichikawa T, Jin Y, Hofseth LJ, Nagarkatti $P$, Nagarkatti M, Windust A, Cut T, An essential role of Nrf2 in American ginseng-mediated antioxidative actions in cardiomyocytes. $J$ Ethnopharmacol., 2010; 130 (2): 222-230.

16. Wu Y, Xia ZY, Dou J, Zhang L, Xu JJ, Zhao B, Lei $\mathrm{S}$, Liu HM, Protective effect of ginsenoside $\mathrm{Rb}_{1}$ against myocardial ischemia/reperfusion injury in streptozotocin-induced diabetic rats. Mol Biol Rep., 2011; 38 (7): 4327-4335.

17. Kim BH, Lee YG, Park TY, Kim HB, Rhee MH, Cho JY, Ginsenoside Rp1, a ginsenoside derivative, blocks lipopolysaccharide-induced interleukin-1 beta production via suppression of the NF-kappaB pathway. Planta Med., 2009; 75 (4): 321-326.

18. Sun B, Xiao J, Sun XB, Wu Y, Notoginsenoside $R_{1}$ attenuates cardiac dysfunction in endotoxemic mice: an insight into oestrogen receptor activation and PI3K/Akt signalling. $\mathrm{Br} J$ Pharmacol., 2013; 168 (7): 1758-1770.

19. Jeon WJ, Oh JS, Park MS, Ji GE, Antihyperglycemic effect of fermented ginseng in type 2 diabetes mellitus mouse model. Phytother Res., 2013; 27 (2): 166-172.

20. Liu Z, Li W, Li X, Zhang M, Chen L, Zheng YN, Sun GZ, Ruan CC, Antidiabetic effects of malonyl ginsenosides from Panax ginseng on type 2 diabetic rats induced by high-fat diet and streptozotocin. $J$ Ethnopharmacol., 2013; 145 (1): 233-240.

21. Woo HC, Shin BK, Cho I, Koo H, Kim M, Han J, Anti-obesity effect of carbon dioxide supercritical fluid extracts of Panax ginseng C.A. Meyer. $J$ Korean Soc Appl Biol and Chem., 2011; 54(5): 738-743.

22. Hostettmann K, Marston A, Saponins. Cambridge University Press: Cambridge, New York, 1995.

23. Stanimirova R, Marinova $\mathrm{K}$, Tcholakova $\mathrm{S}$, Denkov N, Stoyanov S., Pelan E, Surface rheology of saponin adsorption layers. Langmuir., 2011; 27: 12486-12498.

24. Mitra S, Dungan SR, Micellar properties of Quillaja saponin. 1. Effects of temperature, salt, and $\mathrm{pH}$ on solution properties. J Agri Food Chem, 1997; 45: 1587-1595.

25. Decroos K, Vincken JP, van Koningsveld GA, Gruppen H, Verstraete W, Preparative chromatographic purification and surfactant properties of individual soya saponins from soy hypocotyls. Food Chem., 2007; 101: 324-333.

26. Xiong J, Guo J, Huang L, Meng B, Ping Q, Selfmicelle formation and the incorporation of lipid in the formulation affect the intestinal absorption of Panax notoginseng. Int J Pharm., 2008; 360: 191-196.

27. Ribeiro BD, Alviano DS, Barreto DW, Coelho MAZ, Functional properties of saponins from sisal (Agave sisalana) and juá (Ziziphus joazeiro): critical micellar concentration, antioxidant and antimicrobial activities. Colloids Surf A Physicochem Eng Asp., 2013; 436: 736-743.

28. Wang L, Weller CL., Recent advances in extraction of nutraceuticals from plants. Trends Food Sci Technol., 2006; 17: 300-312.

29. Wu J, Lin L, Chau FT, Ultrasound-assisted extraction of ginseng saponins from ginseng roots and cultured ginseng cells. Ultrason Sonochem., 2001; 8: 347-352.

30. Kwon JH, Belanger JM, Pare J, Yaylayan VA, Application of the microwave-assisted process (MAPTM) to the fast extraction of ginseng saponins. F Res International, 2003; 36: 491-498.

31. Reverchon E, Supercritical fluid extraction and fractionation of essential oil sand related products. J Supercrit Fluids, 1997; 10: 1-37.

32. Reverchon E, De Marco I, Supercritical fluid extraction and fractionation of natural matter. $J$ Supercrit Fluids, 2006; 38: 146-166.

33. Martín L, Mainar AM, González-Coloma A, Burillo J, Urieta JS, Supercritical fluid extraction of wormwood (Artemisia absinthium L.). J Supercrit Fluids, 2011; 56: 64-71.

34. Benova B, Adam M, Pavlíková P, Fischer J, Supercritical fluid extraction of piceid, resveratrol and emodin from Japanese knotweed. $J$ Supercrit Fluids, 2010; 51: 325-330.

35. King J, Modern supercritical fluid technology for food applications. Annu Rev Food Sci Technol., 2014; 5: 215-238.

36. Zosel K, Process for recovering caffeine. US Patent No. 3806619, 1974.

37. Zekovic Z, Pfaf-Sovljanski I, Grujic O, Supercritical fluid extraction of hops. J Serb Chem Soc., 2007; 72: 81-87.

38. Brondz I, Supercritical fluids: supercritical fluid extraction (SFE) and supercritical fluid chromatography. Special issue. Am J Anal Chem., 2012; 3(12A): 867-869.

39. Herrero M, Mendiola JA, Cifuentes A, Ibanez E, Supercritical fluid extraction: recent advances and applications. J Chromatogr., 2010; 1217: 2495511.

40. Baig MN, Santos RCD, Zetzl C, King J, Pioch D, Bowra S, Evaluation and modeling the utility of 
FARMACIA, 2019, Vol. 67, 2

$\mathrm{SC}-\mathrm{CO}_{2}$ to support efficient lipase mediated esterification. Enzyme Microb Technol., 2011; 49: 420-426.

41. Weidner E, Brake C, Richter D, Thermo-and fluiddynamic aspects of the hydrogenation of triglycerides and esters in the presence of supercritical fluids. in Supercritical Fluids as Solvents and Reaction Media: editor G Brunner,. Elsevier, Amsterdam, 2004; 269-294.

42. Turner C, Jacobson G, Almgren K, Waldeback M, Sjoberg PJR, Subcritical water extraction and $\beta$ glucosidase-catalyzed hydrolysis of quercetin glycosides in onion waste. Green Chem., 2006; 8: 949-959.

43. Weidner E, High pressure micronization for food applications. J Supercrit Fluids, 2009; 47: 556-565.

44. Martinez JL, Supercritical Fluid Extraction of Nutraceuticals and Bioactive Compounds. CRC Press: Boca Raton, Florida, 2008.

45. King JW, Supercritical fluid-based extraction/ processing: then and now. Inform, 2012; 23: 122-125.

46. Clark $\mathrm{JH}$, Introduction to green chemistry in Alternatives to Conventional Food Processing: editor A Proctor, RSC, Cambridge, United Kingdom, 2011; 1-10.

47. Pandey A, Larroche C, Ricke SC, Dussap CG, Gnansounou E, Biofuels-Alternative Feedstocks and Conversion Processes. Elsevier: Amsterdam, 2011.

48. Bergeron C, Carrier DJ, Ramaswamy S, Biorefinery Co-Products Phytochemicals, Primary Metabolites and Value-Added Biomasss Processing. Wiley: West Sussex, United Kingdom, 2012.

49. Ramaswamy S, Huang HJ, Ramarao BV, Separation and Purification Technologies in Biorefineries. Wiley: West Sussex, United Kingdom, 2013.

50. Thompson PB, The agricultural ethics of biofuels: The food versus fuel debate. Agriculture, 2012; 2 : 339-358.

51. Catchpole OJ, Grey JB, Noermark KA, Fractionation of fish oils using supercritical $\mathrm{CO}_{2}$ and $\mathrm{CO}_{2}+$ ethanol mixtures. $J$ Supercrit Fluids, 2000; 19: 25-37.

52. Fornari T, Tenllado D, Torres C, Reglero G, Supercritical phase equilibria modeling of glyceride mixtures and carbon dioxide using the group contribution EoS. J Thermodyn., 2011; 2011: 1-9.

53. Brunner G, Supercritical fluids: technology and applications to food processing. J Food Eng., 2005; 67: 21-33.

54. Brunner G, Machado NT, Process design methodology for fractionation of fatty acids from palm fatty acid distillates in countercurrent packed columns with supercritical CO2. J Supercrit Fluids, 2012; 66: 96-110.

55. Dunford NT, King JW, Supercritical fluid fractionation process for phytosterol ester enrichment in vegetable oils. US Patent No. 6677469 B1, 2004.

56. Reverchon E, De Marco I, Supercritical fluid extraction and fractionation of natural matter. $J$ Supercrit Fluids, 2006; 38: 146-66.
57. Ramirez P, Garcia-Risco MR, Santoyo S, Senorans FJ, Ibanez E, Reglero G, Isolation of functional ingredients from rosemary by preparative supercritical fluid chromatography (SFC). J Pharm Biomed Anal., 2006; 41: 1606-1613.

58. Cristancho CAM, Peper S, Johannsen $M$, Supercritical fluid simulated moving bed chromatography for the separation of ethyl linoleate and ethyl oleate. J Supercrit Fluids, 2012; 66: 129136.

59. Montanes F, Catchpole OJ, Tallon S, Mitchell K, Lagutin K, Semi-preparative supercritical chromatography scale plant polyunsaturated fatty acids purification. J Supercrit Fluids, 2013; 79: 4645.

60. Wang HC, Chen CR, Chang CJ, Carbon dioxide extraction of ginseng root hair oil and ginsenosides. Food Chem., 2001; 72: 505-509.

61. McHugh MA, Krukonis VJ, Supercritical fluid extraction: principle and practice. Butterworth Publisher: Boston, 1986.

62. Friedrich JP, List GR, Heakin AJ, Petroleum-free extraction of oil from soybeans with supercritical $\mathrm{CO}_{2} . J$ Am Oil Chem Soc., 1982; 59: 288-292.

63. Garcia A, Lucas AD, Rincon J, Alvarez A, Garcia I, Garcia MA, Supercritical carbon dioxide extraction of fatty and waxy material from rice bran. J Am Oil Chem Soc., 1996; 73(8): 1127-1131.

64. Wood JA, Bernards MA, Wan-kei W, Charpentier PA, Extraction of ginsenosides from North American ginseng using modified supercritical carbon dioxide. J Supercrit Fluids, 2006; 39: 40-47.

65. Court WA, Hendel JG, Elmi J, Reversed-phase high performance liquid chromatographic determination of ginsenosides of Panax quinquefolium. J Chromatogr., 1996; A(755): 11-17.

66. Assinewe VA, Baum BR, Gagnon D, Arnason JT, Phytochemistry of wild populations of Panax quinquefolius L. (North American ginseng). J Agric Food Chem., 2003; 51: 4549-4553.

67. Kite GC, Howes MR, Leon CJ, Simmonds MSJ, Liquid chromatography/mass spectrometry of malonyl-ginsenosides in the authentication of ginseng, Rapid Commun Mass Spectrom., 2003; 17: 238-244.

68. Gebhardt S, Bihler S, Schubert-Zsilavecz M, Riva S, Monti D, Falcone L, Danieli B, Biocatalytic generation of molecular diversity: modification of ginsenoside $\mathrm{Rb}_{1}$ by $\beta$-1,4-galactosyltransferase and Candida antarctica lipase. Helv Chim Acta, 2002; 85(7): 1943-1959.

69. Luo D, Qiu T, Lu Q, Ultrasound-assisted extractions of ginsenosides in supercritical $\mathrm{CO}_{2}$ reverse microemulsions. J Sci Food Agric., 2007; 87: 431-436.

70. Yu IL, Yu ZR, Koo M, Wang B, A continuous fractionation of ginsenosides and polysaccharides from Panax ginseng using supercritical carbon dioxide technology. J Food Proces Preserv., 2015; 40(4): 743-748.

71. King JW, Advances in critical fluid technology for food processing. Food Sci Technol Today, 2000; 14: $186-191$ 
72. Mendiola JA, Garcia-Martinez D, Rupérez FJ, Martín-Álvarez PJ, Reglero G, Cifuentes A, Barbas C, Ibañez E, Señoráns FJ, Enrichment of vitamin E from Spirulina platensis microalga by SFE. $J$ Supercrit Fluids, 2008; 43: 484-489.

73. Kang KS, Yamabe N, Kim HY, Okamoto T, Sei Y, Yokozawa $\mathrm{T}$, Increase in the free radical scavenging activities of American ginseng by heat processing and its safety evaluation. $J$ Ethnopharmacol., 2007; 113: 225-232.

74. Hu C, Kitts DD, Free radical scavenging capacity as related to antioxidant activity and ginsenoside composition of Asian and North American ginseng extracts. J Am Oil Chem Soc., 2001; 78: 249-255.

75. Valko M, Leibfritz D, Moncol J, Cronin MT, Mazur M, Telser J, Free radicals and antioxidants in normal physiological functions and human disease. Int J Biochem Cell Biol., 2007; 39: 44-84.

76. Chien YS, Yu Z, Koo M, Wang B, Supercritical fluid extractive fractionation - study of the antioxidant activities of Panax ginseng. Sep Sci Technol., 2016; 51(6): 954-960.

77. Bitencourt RG, Queiroga CL, Montanari Junior I, Cabral FA, Fractionated extraction of saponins from Brazilian ginseng by sequential process using supercritical $\mathrm{CO}_{2}$, ethanol and water. $J$ Supercrit Fluids, 2015; 92: 272-281.

78. Leal PF, Kfouri MB, Alexandre FC, Agundes FHRF, Prado JM, Toyama MH, Meireles MAA, Brazilian Ginseng extraction via LPSE and SFE: Global yields, extraction kinetics, chemical composition and antioxidant activity. $J$ Supercrit Fluids, 2010; 54: 38-45.

79. Meireles MAA, Supercritical extraction from solid: process design data (2001-2003). Curr Opin Solid St M., 2003; 7: 321-330.

80. Quan C, Li SF, Tian SJ, Xu H, Lin A, Gu L, Supercritical fluid extraction and clean-up of organochlorine pesticides in ginseng. $J$ Supercrit Fluids, 2004; 31: 149-157.

81. Langenfeld JJ, Hawthorne SB, David JM, Pawliszyn J, Effects of temperature and pressure on supercritical fluid extraction efficiencies of polycyclic aromatic hydrocarbons and polychlorinated biphenyls. Anal Chem., 1993; 65: 338.

82. Ashraf-Khorassani M, Gidanian S, Yamini Y, Effect of pressure, temperature, modifier, modifier concentration, and sample matrix on the supercritical fluid extraction efficiency of different phenolic compounds J Chromatogr Sci., 1995; 33: 658.

83. Pawliszyn J, Kinetic-model of supercritical fluid extraction. J Chromatogr Sci., 1993; 31(1): 31-37.

84. Owen WP, Maxwell RJ, Isolation of sulfonamides from fortified chicken tissues with supercritical $\mathrm{CO}_{2}$ and in-line adsorption. $J$ Chromatogr Sci., 1994; 32: 290 .

85. Huang $\mathrm{Y}$, Zhang $\mathrm{T}$, Crommen J, Jiang Z, Fast separation of triterpenoid saponins using supercritical fluid chromatography coupled with single quadrupole mass spectrometry. $J$ Pharm Biomed Anal., 2016; 121: 22-29.

86. Agrawal H, Kau N, Paradkar AR, Mahadik KR, Separation of bacoside A3 and bacopaside II, major triterpenoid saponins in bacopa monnieri, by HPTLC and SFC Application of SFC in implementation of uniform design for herbal drug standardization with thermodynamic study. Acta Chromatographica, 2006; 17: 125-150.

87. Ashraf-Khorassani M, Taylor LT, Subcritical fluid chromatography of water soluble nucleobases on various polar stationary phases facilitated with alcohol modified $\mathrm{CO}_{2}$ and water as the polar additive. J Sep Sci, 2010; 33 (11): 1682-1691.

88. Wang SF, Elshani S, Wai CM, Selective extraction of mercury with ionisable crown ethers in supercritical carbon dioxide. Anal Chem., 1995; 67: 919-923.

89. Taylor LT, Packed column supercritical fluid chromatography of hydrophilic analytes via waterrich modifiers. J Chromatogr A, 2012; 1250: 196204.

90. Huang Y, Zhang T, Zhao Y, Zhou H, Tang G, Fillet M, Crommen J, Jiang Z, Simultaneous analysis of nucleobases, nucleosides and ginsenosides in ginseng extracts using supercritical fluid chromatography coupled with single quadrupole mass-spectrometry. J Pharm Biomed Anal., 2017; 144: 213-219.

91. Samimi R, Xu WZ, Alsharari Q, Charpentier PA, Supercritical fluid chromatography of North American ginseng extract. J Supercrit Fluids, 2014; 86: 115-123.

92. Agrawal H, Kau N, Paradkar AR, Mahadik KR, Separation of bacoside $\mathrm{A}_{3}$ and bacopaside II, major triterpenoid saponins in bacopa monnieri, by HPTLC and SFC Application of SFC in implementation of uniform design for herbal drug standardization with thermodynamic study. Acta Chromatogr., 2006; 17: 125-150. 